\title{
Vplyv učebného programu pre florbal na herné zručnosti žiakov základnej školy
}

\section{An influence of the learning program for floorball on game skills of pupils in elementary school}

\author{
Daniel Baránek
}

Fakulta humanitných vied Univerzity Mateja Bela, Banská Bystrica, Slovensko

\begin{abstract}
Abstrakt:
Príspevok sa zaoberá športovou hrou florbal v rámci školskej telesnej výchovy. Skúma učebný program pre vyučovanie športovej hry florbal a stav vybraných herných zručností žiakov vo florbale na druhom stupni základnej školy. Cielom výskumu bolo overit' vplyv nami zostaveného učebného programu pre vyučovanie športovej hry florbal na herné zručnosti žiakov druhého stupňa základnej školy.

Výskum sme realizovali na ZŠ Sv. Gorazda Žilina počas 16 vyučovacich hodin v rámci predmetu Telesná a športová výchova. Žiaci postupovali pri vyučovaní florbalu podl'a nami zostaveného učebného programu. Na zistenie stavu herných zručností žiakov sme použili 6 testov: vedenie loptičky VL, strel'ba po vedení loptičky $S P V L$, prihrávka po zemi forhend PPZF, prihrávka po zemi bekhend PPZB, prihrávka po zemi po vedení loptičky forhend PPVLF a prihrávka po zemi po vedeni loptičky bekhend PPVLB. Vstupný stav a výstupný stav týchto testov sme dali pomocou testov štatistickej významnosti do vzájomného vztahu, na základe ktorého sme zistili, že medzi vstupnými a výstupnými stavmi žiakov sú štatisticky významné zmeny $(p<0,05)$ vo všetkých nami vybraných testoch herných zručností VL, SPVL, PPZF, PPZB, PPVLF, PPVLB.
\end{abstract}

\section{Abstract:}

Dissertation deals with sport game floorball as a part of school physical education. Dissertation examines learning program for teaching floorball and degree of selected game skills of pupils in floorball in elementary school. The aim of this work was to check an influence of the learning program for teaching a sport game floorball on game skills of pupils in elementary school.

The research was realized on one set of pupils (boys) of fifth grade in elementary school in St. Gorazd school Zilina during sixteen lessons of Physical Education and Sports. Students proceeded in teaching by us created teaching program. To find out the status of game skills of pupils, we used six tests: leading ball VL, shooting after leading ball SPVL, pass on the floor forehand PPVLF, pass on the floor backhand PPZB, pass on the floor after leading ball forehand PPVLF and pass on the floor after leading ball backhand PPVLB. Input and output aspects of these tests were given by statistical methods to correlation. Correlation showed that there are statistically significant changes $(p<0,05)$ between input and output aspects in all, by us chosen, tests of game skills VL, SPVL, PPZF, PPVLF, PPVLB.

Klúčové slová: florbal, žiaci, základná škola, herné zručnosti, učebný program

Key words: floorball, pupils, elementary school, game skills, learning program

\section{ÚVOD}

Príspevok je venovaný športovej hre florbal v školskej telesnej výchove, učebnému programu pre vyučovanie florbalu a stavu vybraných herných zručností vo florbale žiakov (chlapcov) 5. ročníka základnej školy.

V dnešnej dobe sa objavujú v rámci predmetu Telesná a športová výchova nové netradičné pohybové hry, športové hry. Vyučujúci ich zarad'ujú čoraz častejšie do edukačného procesu, kvôli spestreniu vyučovania. 
Vychádzajú tiež z požiadaviek žiakov, ktorí majú záujem o nové netradičné športy. Školská reforma im oproti minulosti dáva na to väčší priestor. Jednou z týchto netradičných športových hier je aj športová hra florbal. Myslíme si, že žiaci si ju oblúbili a vel'mi radi sa k nej vracajú, pretože je alternatívou l'adového hokeja, ktorý patrí medzi najpopulárnejšie športy na Slovensku. Baránek (2013) vo výsledkoch svojho prieskumu uvádza, že zo 650 žiakov základných škôl 70 \% z nich vníma zaradenie florbalu v školskej telesnej výchove pozitívne, 22 $\%$ neutrálne a $8 \%$ negatívne.

Bohužial' vel'ké rezervy vidíme vo florbalovom vzdelávaní. Deficit, s ktorým sa stretávajú vyučujúci je nedostatok literárnych prameňov, ktoré by im ozrejmili ako viest' žiakov vo vyučovaní florbalu, prípadne hodnotili stav herných zručností, herného výkonu žiakov. Na Slovensku existuje iba jedna oficiálne vydaná publikácia (Ondruš, 2010), ktorá pomáha vyučujúcim pri vzdelávaní žiakov o tomto pre nich určite zaujímavom športe. Môžu sa väčšinou stretnút' len so zahraničnou literatúrou. Tejto problematike sa okrem iných venujú Zlatník (2001, 2004), Skružný (2005), Kysel (2011) a my sme vychádzali z ich publikácií pri zostavovaní nášho učebného programu. Na Slovensku sa obdobnou problematikou zaoberajú Sekelský (2012) Sujová, Vladovičová (2012). Taktiež budeme vychádzat' z platného štátneho a školského vzdelávacieho programu pre telesnú a športovú výchovu na 2. stupni základných škôl od Hausera (2008), štandardizovaných testov herných zručností futbalistov od Holienku (2004).

Prostredníctvom nášho príspevku by sme chceli prispiet' k osvete a zvýšeniu kvality vyučovania florbalu na základných školách. Ciel’om výskumu bolo overit’ vplyv učebného programu pre vyučovanie športovej hry florbal na herné zručnosti žiakov druhého stupňa základnej školy. Samotný výskum a jeho výsledky by mali prispiet' k ekonomickému a efektívnemu procesu vyučovania florbalu v rámci predmetu Telesná a športová výchova. Predmet Telesná a športová výchova sa touto formou môže stat' atraktívnejším pre žiakov svojím obsahom i náplňou v rámci vyučovacích hodín.

\section{METODIKA}

Objektom nášho výskumu boli žiaci 5. ročníka (chlapci) druhého stupňa. Výskum sme realizovali v mesiacoch september až november 2012 v rámci predmetu Telesná a športová výchova na ZŠ Sv. Gorazda Žilina. Výber žiakov bol náhodný, jednalo sa o všetkých cvičiacich žiakov (chlapcov) 5. A a 5. B triedy, ktorí majú hodiny predmetu Telesná a športová výchova spoločné. Do výskumu sa zapojilo 17 žiakov, ale pri vyhodnocovaní sme brali do úvahy výsledky 15 žiakov, ktorí absolvovali vstupné aj výstupné merania. Využili sme časovú dotáciu 16 vyučovacích hodín (45 minút) v rámci tematických celkov testovanie (4 vyučovacie hodiny), povinne výberový tematický celok (12 vyučovacích hodín). Nami zostavený učebný program sme implementovali do edukačného procesu počas 12 vyučovacích hodín. Vstupné testy herných zručností absolvovali žiaci na prvej a druhej hodine. Nami zostavený učebný program pre vyučovanie športovej hry florbal sme zaradili do vyučovacieho procesu počas tretej až štrnástej vyučovacej hodiny. Výstupné merania, testy herných zručností absolvovali žiaci na pätnástej a šestnástej vyučovacej hodine.

\section{METÓDY ZÍSKAVANIA FAKTOGRAFICKÉHO MATERIÁLU}

1. Literárna metóda

Literárnu metódu sme využili najmä na začiatku výskumu pri tvorbe teoretických východísk skúmanej problematiky.

2. Obsahová analýza dokumentov

Obsahovú analýzu dokumentov sme využili na analýzu informácii získaných počas obdobia nášho výskumu.

3. Testy herných zručností

Testy herných zručností sme využili pri zist'ovaní stavu vybraných herných zručností žiakov z florbalu pred (vstupné merania) a po kváziexperimente (výstupné merania). Testová batéria pre hodnotenie stavu vybraných herných zručností žiakov v športovej hre florbal pozostávala z neštandardizovaných testov zameraných na vedenie loptičky (slalom) VL, strel'bu po vedení loptičky (slalome) SPVL, prihrávku po zemi (forhend, bekhend) PPZF - PPZB, prihrávku po zemi po vedení loptičky (forhend, bekhend) PPVLF - PPVLB. Pri zostavovaní testov sme vychádzali z modifikácie testov herných zručností pre futbalistov od Holienku (2004) a literatúry od Staršieho, Jančokovej, Výboha (1999). 
Popis testov a ich prevedenie:

VL - Prejdenie vymedzenej trate (5 kužel'ov, mét vo vzdialenosti 1 meter od seba) s loptičkou na hokejke $\mathrm{v}$ čo najkratšom čase. Žiak vedie loptičku striedavo forhendovou a bekhendovou stranou čepele hokejky pomedzi méty tam aj spät'.

SPVL - Presnost' strel'by po vedení loptičky na vzdialenost' 10 metrov. Žiak 5krát vedie loptičku pomedzi kužele smerom k bráne a následne zo vzdialenosti 10 metrov striel’a forhendovou stranou čepele hokejky na bránu.

PPZF, PPZB - Presnost' prihrávky po zemi na vzdialenost' 10 metrov. Žiak 5krát za sebou prihráva loptičku forhendovou a bekhendovou stranou čepele hokejky po zemi do postavenej malej brány (dve méty 1 meter od seba) na vzdialenost' 10 metrov.

PPVLF, PPVLB - Presnost' prihrávky po zemi po vedení loptičky na vzdialenost' 10 metrov. Žiak 5 krát za sebou prihráva loptičku po vedení forhendovou a bekhendovou stranou čepele hokejky po zemi do postavenej malej brány (dve méty 1 meter od seba) na vzdialenost' 10 metrov.

4. Kváziexperiment

Využívali sme terénny, dvojskupinový, s viacnásobným meraním závislej premennej pred a po kváziexperimentálnom zásahu. Kvázixperimentálnym zásahom rozumieme zaradenie nami zostaveného učebného programu pre vyučovanie športovej hry florbal do edukačného procesu. Závisle premenná bol stav herných zručností žiakov pred a po zaradení učebného programu. Kváziexperimentálnym činitel'om bol nami zostavený učebný program pre vyučovanie športovej hry florbal. Učebný program bol zameraný na rozvoj herných zručností žiakov: vedenie loptičky, uvol'ňovanie hráča s loptičkou, prihrávku a spracovanie loptičky, strel'bu loptičky.

5. Pozorovanie

V našom výskume sme pozorovanie využili ako diagnostickú činnost', pri ktorej sme kontrolovali správnost' vykonania jednotlivých testov herných zručností žiakov a priebeh výskumu.

\section{Meranie}

Meranie sme vo výskume využili na zaznamenanie hodnôt pri testoch herných zručností žiakov.

\section{METÓDY SPRACOVANIAA VYHODNOCOVANIA FAKTOGRAFICKÉHO MATERIÁLU KVALITATÍVNE METÓDY}
1. kazuistika
2. analýza
3. syntéza
4. indukcia
5. dedukcia

\section{KVANTITATÍVNE METÓDY}

Kvantitatívne metódy, ktoré sme využili pri spracovávaní výsledkov, sme vyhodnotili v programe Microsoft Office Word a Excel. Štatistická analýza bola realizovaná pomocou software PASW Statistics 18.

$\mathrm{Na}$ štatistické spracovanie, vyhodnotenie výskumu sme použili Wilcoxonov neparametrický test pre závislé výbery. Významnost' sme zist'ovali na štandardne použivanej 5\% hladine $\alpha$ medzi vstupnými a výstupnými stavmi herných zručností žiakov.

Pri kvantitatívnom spracovaní výsledkov výskumu sme použili aj základné opisné charakteristiky hodnôt výkonov aritmetický priemer (x), smerodajná odchýlka (s), medián (med (x)), maximum nameraných hodnôt (max) a minimum nameraných hodnôt (min).

\section{VÝSLEDKY}

\section{Štatistická významnost' zmeny v testoch herných zručností žiakov}

Štatistickú významnost' zmeny v testoch herných zručností medzi vstupným a výstupným meraním, ktoré dosiahli žiaci uvádzame $v$ tabul'kách 1 a 2. Pri porovnaní priemerných hodnôt a mediánov medzi vstupným a výstupným meraním $v$ testoch na zistenie stavu herných zručností žiakov vidiet', že celkovo sa žiaci zlepšili vo všetkých testoch VL, SPVL, PPZF, PPZB, PPVLF, PPVLB. Štatisticky významné zmeny $(p<0,05)$ medzi vstupným a výstupným meraním sme zaznamenali vo všetkých testoch herných zručností VL, SPVL, PPZF, PPZB, PPVLF, PPVLB. Môžeme konštatovat', že žiaci kváziexperimentálnej skupiny pri výstupných meraniach 
dosiahli štatisticky významné zmeny $(\mathrm{p}<0,05)$ vo všetkých z nami vybraných testoch herných zručností vo florbale.

V teste VL si môžeme všimnút' zmenu priemernej hodnoty z 13,82 (s) na 12,05 (s) a mediánu z 13,9 (s) na 11,5 (s), čo predstavuje štatisticky významnú zmenu $(\mathrm{p}<0,05)$. V teste SPVL došlo k zmene priemernej hodnoty z 1,3 (n) na 2,3 (n) a mediánu z 1 (n) na 2 (n), čo predstavuje štatisticky významnú zmenu (p $<0,05)$. V teste PPZF došlo k zmene priemernej hodnoty z 1,7 (n) na 2,6 (n) a medián 2 (n) sa nezmenil, čo predstavuje štatisticky významnú zmenu (p < 0,05). V teste PPZB došlo $\mathrm{k}$ zmene priemernej hodnoty z 1,1 (n) na 1,9 (n) a mediánu z 1 (n) na 2 (n), čo predstavuje štatisticky významnú zmenu $(\mathrm{p}<0,05)$.

Tabul'ka 1: Štatistická významnost' zmeny v testoch herných zručností žiakov

\begin{tabular}{|c|c|c|c|c|c|c|c|c|}
\hline & \multicolumn{2}{|c|}{ VL } & \multicolumn{2}{c|}{ SPVL } & \multicolumn{2}{c|}{ PPZF } & \multicolumn{2}{c|}{ PPZB } \\
\hline $\mathrm{n}=15$ & VST & VÝST & VST & VÝST & VST & VÝST & VST & VÝST \\
\hline $\mathrm{X}$ & 13,82 & 12,05 & $1,3(\mathrm{n})$ & $2,3(\mathrm{n})$ & $1,7(\mathrm{n})$ & $2,6(\mathrm{n})$ & $1,1(\mathrm{n})$ & $1,9(\mathrm{n})$ \\
& $(\mathrm{s})$ & $(\mathrm{s})$ & & & & & & \\
\hline $\mathrm{S}$ & $3,5(\mathrm{~s})$ & $3,24(\mathrm{~s})$ & $0,9(\mathrm{n})$ & $1(\mathrm{n})$ & $1(\mathrm{n})$ & $1,1(\mathrm{n})$ & $0,8(\mathrm{n})$ & $1,1(\mathrm{n})$ \\
\hline med $(\mathrm{x})$ & $13,9(\mathrm{~s})$ & $11,5(\mathrm{~s})$ & $1(\mathrm{n})$ & $2(\mathrm{n})$ & $2(\mathrm{n})$ & $2(\mathrm{n})$ & $1(\mathrm{n})$ & $2(\mathrm{n})$ \\
\hline Max & $21,6(\mathrm{~s})$ & $16,5(\mathrm{~s})$ & $3(\mathrm{n})$ & $4(\mathrm{n})$ & $3(\mathrm{n})$ & $5(\mathrm{n})$ & $3(\mathrm{n})$ & $4(\mathrm{n})$ \\
& & & & & & & & \\
\hline Min & $8,7(\mathrm{~s})$ & $7,5(\mathrm{~s})$ & $0(\mathrm{n})$ & $1(\mathrm{n})$ & $0(\mathrm{n})$ & $1(\mathrm{n})$ & $0(\mathrm{n})$ & $0(\mathrm{n})$ \\
\hline$*$ & \multicolumn{3}{|c|}{$(\mathrm{p}<0,05) \mathrm{sV}$} & \multicolumn{3}{c}{$(\mathrm{p}<0,05) \mathrm{sV}$} & \multicolumn{3}{c|}{$(\mathrm{p}<0,05) \mathrm{sV}$} & $(\mathrm{p}<0,05) \mathrm{sV}$ \\
\hline
\end{tabular}

V teste PPVLF si môžeme všimnút' zmenu priemernej hodnoty z 1,1 (n) na 1,8 (n) a mediánu z 1 (n) na 2 (n), čo predstavuje štatisticky významnú zmenu $(\mathrm{p}<0,05)$. V teste PPVLB došlo k zmene priemernej hodnoty z 0,8 (n) na 1,3 (n) a medián 1 (n) sa nezmenil, čo predstavuje štatisticky významnú zmenu $(\mathrm{p}<0,05)$. Ked' sme spolu spočítali priemerné hodnoty a mediány testov PPZF a PPZB, vyšlo nám, že v PPZ došlo k zmene priemernej hodnoty z 2,8 (n) na 4,5 (n) a mediánu z 3 (n) na 4 (n), čo predstavuje štatisticky významnú zmenu (p < 0,05). Ked' sme spolu spočítali priemerné hodnoty a mediány testov PPVLF a PPVLB, vyšlo nám, že v PPVL došlo k zmene priemernej hodnoty z 1,9 (n) na 3,0 (n) a mediánu z 2 (n) na 3 (n), čo predstavuje štatisticky významnú zmenu $(\mathrm{p}<0,05)$. 
Tabul'ka 2: Štatistická významnost' zmeny v testoch herných zručností žiakov

\begin{tabular}{|c|c|c|c|c|c|c|c|c|}
\hline & \multicolumn{2}{|c|}{ PPVLF } & \multicolumn{2}{c|}{ PPVLB } & \multicolumn{2}{c|}{ PPZ } & \multicolumn{2}{c|}{ PPVL } \\
\hline $\mathrm{n}=15$ & VST & VÝST & VST & VÝST & VST & VÝST & VST & VÝST \\
\hline $\mathrm{X}$ & $1,1(\mathrm{n})$ & $1,8(\mathrm{n})$ & $0,8(\mathrm{n})$ & $1,3(\mathrm{n})$ & $2,8(\mathrm{n})$ & $4,5(\mathrm{n})$ & $1,9(\mathrm{n})$ & $3,0(\mathrm{n})$ \\
\hline $\mathrm{S}$ & $0,7(\mathrm{n})$ & $0,8(\mathrm{n})$ & $0,7(\mathrm{n})$ & $0,5(\mathrm{n})$ & $1,3(\mathrm{n})$ & $2(\mathrm{n})$ & $1,2(\mathrm{n})$ & $1,1(\mathrm{n})$ \\
\hline med (x) & $1(\mathrm{n})$ & $2(\mathrm{n})$ & $1(\mathrm{n})$ & $1(\mathrm{n})$ & $3(\mathrm{n})$ & $4(\mathrm{n})$ & $2(\mathrm{n})$ & $3(\mathrm{n})$ \\
\hline Max & $2(\mathrm{n})$ & $3(\mathrm{n})$ & $2(\mathrm{n})$ & $2(\mathrm{n})$ & $5(\mathrm{n})$ & $7(\mathrm{n})$ & $4(\mathrm{n})$ & $5(\mathrm{n})$ \\
\hline Min & $0(\mathrm{n})$ & $1(\mathrm{n})$ & $0(\mathrm{n})$ & $1(\mathrm{n})$ & $1(\mathrm{n})$ & $1(\mathrm{n})$ & $0(\mathrm{n})$ & $1(\mathrm{n})$ \\
\hline$*$ & $(\mathrm{p}<0,05) \mathrm{sV}$ & \multicolumn{2}{|c|}{$(\mathrm{p}<0,05) \mathrm{sV}$} & $(\mathrm{p}<0,05) \mathrm{sV}$ & $(\mathrm{p}<0,05) \mathrm{sV}$ \\
\hline
\end{tabular}

\section{Legenda:}

$\mathrm{VL}$ - vedenie loptičky

SPVL - strel'ba po vedení loptičky

PPZF - prihrávka po zemi forhend

PPZB - prihrávka po zemi bekhend

PPVLF - prihrávka po zemi po vedení loptičky forhend

PPVLB - prihrávka po zemi po vedení loptičky bekhend

PPZ - prihrávka po zemi

PPVL - prihrávka po zemi po vedení loptičky

VST - vstupné merania

VÝST - výstupné merania

(s) - časový interval meraný v sekundách

(n) - počet úspešných pokusov

* - štatistická významnost' na 5\% hladine $\alpha(\mathrm{p}<0,05)$

sv - štatisticky významné

\section{DISKUSIA}

Z hladiska ciel'a výskumu sme zist’ovali štatistickú významnost’ zmien medzi vstupným a výstupným meraním. Predpokladali sme, že žiaci ZŠ Sv. Gorazda Žilina po zaradení nami zostaveného učebného programu do vyučovacieho procesu (výstupné merania) budú dosahovat' štatisticky významne zmeny vo všetkých nami vybraných testoch herných zručností. Tento predpoklad sa nám potvrdil a žiaci dosiahli štatisticky významnú zmenu $\quad(p<0,05)$ výstupného stavu v porovnaní so vstupným stavom vo všetkých nami vybraných testoch herných zručností. Štatistická významnost' zmien sa nám teda potvrdila vo všetkých testoch herných zručností VL, SPVL, PPZF, PPZB, PPVLF a PPVLB. Ked' sme spolu spočítali priemerné hodnoty a mediány testov PPZF a PPZB, zistili sme v PPZ štatisticky významnú zmenu $(p<0,05)$ výstupného stavu v porovnaní so vstupným stavom. Ked' sme spolu spočítali priemerné hodnoty a mediány testov PPVLF a PPVLB, zistili sme v PPVL štatisticky významnú zmenu $(p<0,05)$ výstupného stavu v porovnaní so vstupným stavom. Pri porovnaní priemerných hodnôt a mediánov medzi vstupným a výstupným meraním $\mathrm{v}$ testoch na zistenie stavu herných zručností žiakov vidiet', že celkovo sa žiaci kváziexperimentálnej skupiny zlepšili vo všetkých testoch VL, SPVL, PPZF, PPZB, PPVLF, PPVLB. Štatistickú významnost' zmeny v testoch herných zručností medzi vstupným a výstupným meraním, ktoré dosiahli žiaci ZŠ Sv. Gorazda Žilina uvádzame v tabul'kách 1 a 2.

Výskumom sme zistili nové poznatky z oblasti florbalového vzdelávania žiakov základnej školy. Taktiež sme získali obraz o stave herných zručností žiakov základnej školy v športovej hre florbal. Počas realizácie výskumu sa nevyskytli žiadne vážne problémy. Riaditel' oslovenej základnej školy a vyučujúci predmetu Telesná a športová výchova boli ochotní zapojit’ sa do výskumu. Na základe neštandardizovaného rozhovoru, ankety, ktorú sme rozdali vyučujúcim predmetu Telesná a športová výchova a žiakom, ktorí sa zapojili do výskumu, sme dospeli k nasledovným záverom: 
- Vyučujúci predmetu Telesná a športová výchova vnímajú zaradenie nami zostaveného učebného programu pre vyučovanie športovej hry florbal do školskej telesnej výchovy pozitívne.

- Vyučujúci predmetu Telesná a športová výchova využije pri realizácii športovej hry florbal nami zostavený učebný program aj v budúcnosti.

- Žiaci vnímajú zaradenie nami zostaveného učebného programu pre vyučovanie športovej hry florbal v rámci vyučovacej hodiny predmetu Telesná a športová výchova pozitívne.

- $\quad$ Žiaci by sa pri realizácii florbalu v školskej telesnej výchove v budúcnosti venovali najradšej samotnej hre.

\section{ZÁVERY}

V dnešnej dobe sa v školskej telesnej výchove objavujú čoraz častejšie nové, netradičné pohybové aktivity, menej známe pohybové hry, športové hry, ktoré vyučujúci zarad'ujú do vyučovacieho procesu na základe požiadaviek žiakov. Jednou z týchto aktivít je aj športová hra florbal, ktorú si žiaci vel’mi rýchlo oblúbili a ktorá si našla svoje miesto v predmete Telesná a športová výchova. Naším výskumom sme rozšírili poznatky o športovej hre florbal v školskej telesnej výchove. Na základe štúdia odbornej literatúry, realizácie kváziexperimentu, nameraných hodnôt, zistených výsledkov a vlastných praktických skúseností sme dospeli k nasledovným poznatkom:

- Je možné realizovat' výskum, ktorým by sme zist'ovali vplyv učebného programu pre vyučovanie športovej hry florbal na herné zručnosti žiakov v školskej telesnej výchove.

- Vzhl'adom na štúdium odbornej literatúry a výsledky našej práce odporúčamezarad’ovat' nami zostavený učebný program do školskej telesnej výchovy v rámci hodín zameraných na vyučovanie športovej hry florbal, ked’že jeho zaradením môžeme dosiahnut' zlepšenie stavu herných zručností žiakov.

- Pre využitie poznatkov v praxi odporúčame formou seminárov, školení a dostupných publikácií sprístupňovat' vyučujúcim, žiakom poznatky z oblasti vyučovacieho procesu športovej hry florbal v školskej telesnej výchove a poznatky o rozvoji herných zručností žiakov vo florbale.

- Prezentované výsledky odporúčame overit' na početnejšej skupine žiakov, prípadne na viacerých skupinách.

\section{LITERATURA}

BARÁNEK, D. (2013). Florbal v školskej telesnej výchove. In Zborník medzinárodnej vedeckej konferencie Pohyb a zdravie X [CD-ROM]. Trenčín: TNUAD FZ, 2013. s. 34 - 41.

HAUSER, J. (2008). Śtátny vzdelávací program pre 2. stupeň základnej školy v Slovenskej republike. Bratislava: Štátny pedagogický ústav. $40 \mathrm{~s}$.

HOLIENKA, M. (2004). Testy herných zručností pre mladých futbalistov. In Športové hry. Ročník IX., č. $1 / 2004$. s. $23-31$.

KYSEL, J. (2011). Florbal - kompletní pri̊vodce. Praha: Grada publishing. 144 s.

ONDRUŠ, D. (2010). Florbal ako trénovat' a hrat'. Žilina: ŠKK Juventa. 118 s.

SEKELSKÝ, R. (2012). Vyučovanie športových hier v základných školách v Starej Lubovni. Banská Bystrica: KTVŠ FHV UMB. $102 \mathrm{~s}$.

SKRUŽNÝ, Z. a kol. (2005). Florbal. Praha: Grada publishing. 65 s.

STARŠÍ, J., JANČOKOVÁ, L., \& VÝBOH, A. (1999). Teória a didaktika l’adového hokeja I. Banská Bystrica: FHV UMB. $188 \mathrm{~s}$.

SUJOVÁ, L., \& VLADOVIČOVÁ, N. (2012). Vplyv florbalu na rozvoj kondičných schopností detí mladšieho školského veku. In Zborník medzinárodnej vedeckej konferencie Telesná výchova a šport - prostriedok vytvárania vzt'ahu mladej generácie k pohybu a športu. [CD-ROM]. Zvolen: TUZV FÚTVŠ. s. 230 - 234. ZLATNÍK, D. (2004). Florbalový trénink v praxi. Praha: Česká florbalová unie. $61 \mathrm{~s}$. 